No $2009-09$

April

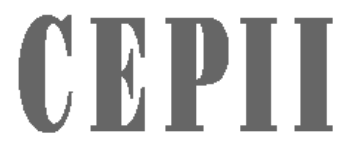

CENTER

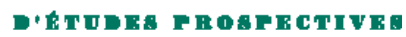

ET D'INFOEMATIONS

INTEENATIONALE:

Market positioning of varieties in world trade: Is Latin America losing out on Asia?

Nanno Mulder, Rodrigo Paillacar \& Soledad Zignago 


\section{TABLE OF CONTENTS}

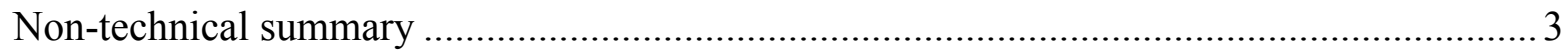

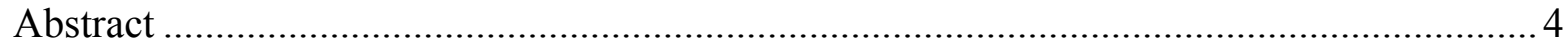

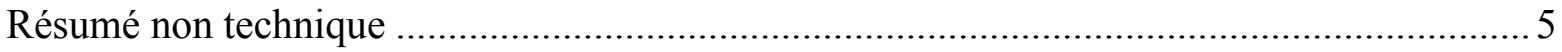

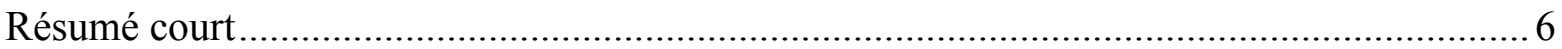

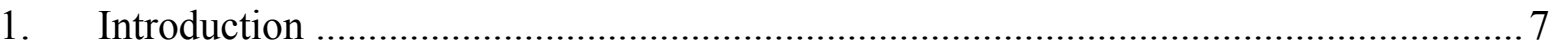

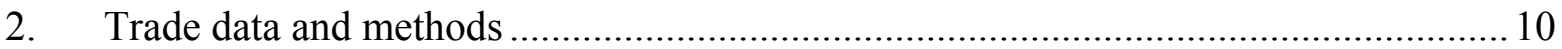

3. World market shares by quality segments and technological contents ....................... 11

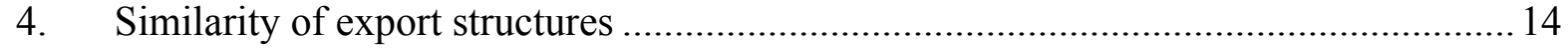

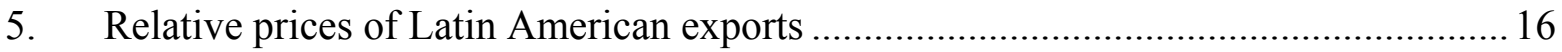

6. Determinants of market positioning in terms of unit values: An econometric analysis19

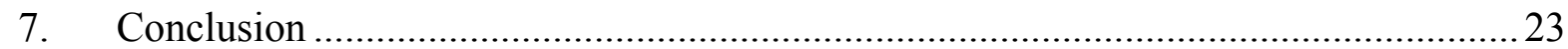

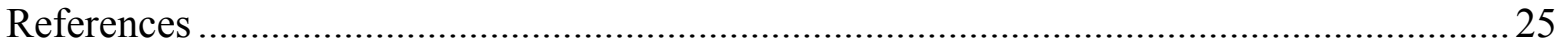

Appendix A: Groupings of countries employed in the analysis.......................................22

Appendix B: Exporters' market shares (as a \% of world trade in each combination

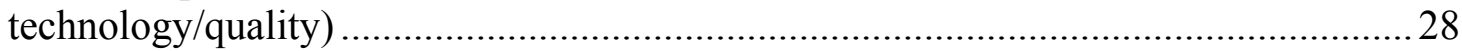

Appendix C: Absolute changes in export similarities at the variety level, 1995- 2004

Appendix D: Distribution of Distance coefficients obtained in the Explanation of Export

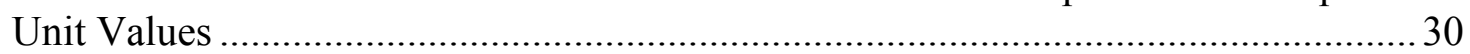

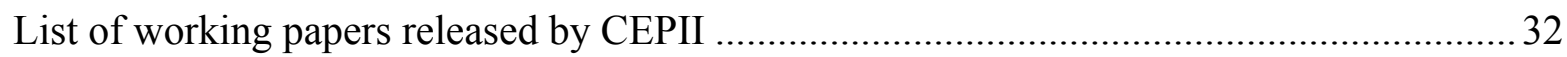




\section{MARKET POSITIONING OF VARIETIES IN WORLD TRADE:} IS LATIN AMERICA LOSING OUT ON ASIA?

\section{NON-TECHNICAL SUMMARY}

There is increasing empirical evidence that trade takes place within products, i.e. across varieties of vertically-differentiated products (qualities), rather than across products or industries. These new findings on trade specialisation and competition have important consequences for the analysis of the transformation and diversification of Latin American exports. The classical view on the upgrading and incorporation of value added in exports was that countries should move away from natural-resource based and low-tech products towards medium and high-tech goods. Under the new paradigm, specialisation can also take place within different qualities of the same product (even resource-based ones) in a process of vertical differentiation. The analysis of trade competition among countries also changes. The basket of products exported by Brazil and Mexico is increasingly similar to that of its Asian competitors. However, if the varieties exported by Latin America differ from the ones exported by the latter (as suggested by their very different prices), the risk of direct competition are substantially reduced.

This paper examines trends in export specialisation in price and quality segments of Latin America and the Caribbean (LAC) and that of its Asian competitors. As in Fontagné, Gaulier and Zignago (2008), we consider three price (or quality) segments to assess export performance. This analysis is done using the BACI database, which is specifically designed for this purpose as it provides harmonised bilateral unit values for most countries in the world at the most disaggregated product-level (5,000 products). We also consider Lall's (2000) technology-content classification, which has been used frequently to study the specialisation developing countries.

Our findings suggest that LAC is losing out on China, notably in the low-quality segment of low-tech products. However, LAC has succeeded to retain their overall market shares, by slightly upgrading the quality and technology content of its exports. Even if this result is largely driven by the performance of Mexico, Brazil and Central America also contribute to this increased sophistication of LAC exports.

The estimations of the similarity in export structures confirm that varieties exported by the two continents are very different. Moreover, prices of LAC exports are much higher than those of China, but relatively similar to the ones of other Asian exporters. 
Finally, econometric tests on the determinants of export unit values of Latin American and Asian products confirm that the type of global competition differs between the two regions: prices play a bigger role in the case of Asian exports, whereas Latin America competes more on quality in world markets.

\begin{abstract}
There is increasing empirical evidence that trade specialisation and competition takes place in varieties rather than in products or industries. This paper examines recent changes in the export specialisation of Latin America and the Caribbean (LAC) and their Asian competitors by looking at their vertical specialisation through prices. Three price (or quality) segments are distinguished to compare export performance between the two regions using our BACI database, which provides harmonised bilateral unit values for most countries in the world at the most disaggregated product-level (5,000 products) for the period 1995 to 2004 . The technology-content of products is also taken into account. The evidence suggests that LAC is losing out on China which is gaining large market shares, notably in the low-quality segment and low-tech segment. However, LAC has retained its initial overall market share, by slightly upgrading the quality and technology content of its exports. Our estimates of similarities in export structures confirm that varieties exported by the two continents are very different. Moreover, LAC export prices are much higher than those of China, but relatively similar to the ones of other Asian nations. Finally, we analyse the determinants of unit values of Latin American and Asian exports. Econometric tests confirm that the type of global competition differs between the two regions: prices play a bigger role in the case of Asian exports, whereas Latin America competes more on quality in world markets.
\end{abstract}

JEL Classification: F1, F4

Key Words: $\quad$ Export Unit Values, Vertical Differentiation, Latin America, Asia. 


\section{LES EXPORTATIONS DE L'AMÉRIQUE LATINE FACE À LA CONCURRENCE ASIATIQUE}

\section{RÉSUMÉ NON TECHNIQUE}

La littérature théorique et empirique récente en commerce international montre que la spécialisation se fait au niveau des variétés, non à celui des produits ou des secteurs. Cette nouvelle compréhension de la spécialisation et de la concurrence internationale a d'importantes conséquences pour l'analyse de la transformation et de la diversification des exportations latino américaines. Selon le schéma classique, les pays abandonnent, au fur et à mesure de leur développement, une spécialisation basée sur les ressources naturelles et les produits manufacturés de basse technologie au profit des secteurs de moyenne, puis de haute technologie. Sous le nouveau paradigme, la spécialisation peut aussi avoir lieu entre variétés verticalement différenciées d'un même produit, c'est-à-dire de qualités différentes. L'analyse de la concurrence entre exportateurs mondiaux s'en trouve ainsi modifiée. Le spectre des produits exportés par le Brésil ou le Mexique ressemble de plus en plus à celui de leurs concurrents asiatiques. Cependant, si les variétés exportées par les uns sont différentes de celles exportées par les autres, comme semblent le suggérer les différences de prix observées, le risque d'une concurrence directe est réduit.

Ce travail examine l'évolution des spécialisations des exportateurs latino américains comparée à celle de leurs concurrents asiatiques, en tenant compte de leurs positionnements en prix. Comme dans Fontagné, Gaulier and Zignago (2008), trois gammes de prix sont considérées pour analyser leurs performances exportatrices. Cela est possible grâce à notre base de données, BACI, qui fournit des valeurs unitaires cohérentes pour pratiquement tous les pays du monde au niveau le plus fin de la nomenclature de commerce international (environ 5000 produits), pour la période 1995-2004. Le contenu technologique des exportations est également pris en compte à l'aide de la classification de Lall (2000), souvent utilisée pour analyser les spécialisations des pays en développement.

Nos résultats indiquent que l'Amérique latine a en effet souffert de la concurrence chinoise qui gagne inexorablement des parts du marché mondial, notamment dans les biens bas de gamme et de bas contenu technologique. Cependant, les pays latino américains dans leur ensemble ont su garder leurs positions du début de période, en montant légèrement en gamme et en contenu technologique de leurs exportations. Même si ce résultat est largement tiré par les performances mexicaines, des pays comme le Brésil ou ceux d'Amérique centrale contribuent également à cette sophistication accrue des exportations latino américaines.

Nos calculs de similarité des structures d'exportation confirment que les variétés latinoaméricaines sont rarement les mêmes que celles vendues par les pays asiatiques. En termes de prix relatifs, les exportations latino américaines diffèrent considérablement des chinoises : les ratios de valeurs unitaires sont en effet plus proches de ceux des autres pays émergents asiatiques que de ceux de la Chine. 
Enfin, notre analyse économétrique s'inscrit dans la littérature récente visant à expliquer les déterminants des valeurs unitaires bilatérales. Les résultats semblent confirmer une spécialisation asiatique sur des produits caractérisés par une concurrence en prix, alors que la spécialisation latino américaine serait plus axée sur une concurrence en qualité.

\section{RÉSUMÉ COURT}

La littérature théorique et empirique récente en commerce international montre que la spécialisation et la concurrence se font au niveau des variétés, non à celui des produits ou des secteurs. Ce travail examine l'évolution des spécialisations des exportateurs latino américains comparée à celle de leurs concurrents asiatiques, en tenant compte de leur différentiation verticale via leurs prix. Trois gammes de prix, ou de qualité, sont considérées pour analyser les performances exportatrices comparées des deux continents grâce à notre base de données, BACI, qui fournit des valeurs unitaires cohérentes au niveau le plus fin de la nomenclature (environ 5000 produits), pour la période 1995-2004. Le contenu technologique des exportations est aussi pris en compte. Nos résultats indiquent que l'Amérique latine a en effet souffert de la concurrence chinoise qui gagne inexorablement des parts du mondial, notamment dans les biens bas de gamme et de bas contenu technologique. Cependant, l'Amérique latine a su garder ses positions initiales, en montant légèrement en gamme et en contenu technologique de ses exportations. Nos calculs de similarité des structures d'exportation confirment que les variétés latino-américaines sont rarement les mêmes que celles vendues par les pays asiatiques. En termes de prix relatifs, les exportations latino américaines diffèrent considérablement des chinoises alors que les prix des autres exportateurs asiatiques sont plus proches des latino américains. Enfin, notre analyse économétrique sur les déterminants des valeurs unitaires bilatérales semble confirmer une spécialisation asiatique sur des produits caractérisés par une concurrence en prix, alors que la spécialisation latino américaine serait plus axée sur une concurrence en qualité.

Classification JEL : F1, F4

Mots-clefs: $\quad$ Différentiation verticale, Qualité, Valeurs unitaires, Amérique latine, Asie. 


\title{
MARKET POSITIONING OF VARIETIES IN WORLD TRADE: IS LATIN AMERICA LOSING OUT ON ASIA?
}

\author{
Nanno Mulder ${ }^{\star}$, Rodrigo Paillacar`\& Soledad Zignago`
}

\section{INTRODUCTION ${ }^{1}$}

Since China joined the World Trade Organisation in December 2001, policy makers and firms in Latin America have become increasingly concerned by the range of sectors facing competition from this country and from other nations in Asia. Several papers by ECLAC, IADB, OECD and World Bank suggest that the Chinese boom in international trade (exports AND imports) is a mixed blessing for Latin America and the Caribbean. On the one hand, part of Latin American exports is complementary to increased Chinese demand for natural resources and their industrial derivatives. On the other hand, there are rising fears in Central America and Mexico that competition from Chinese products may have a devastating effect on clothing maquilas, electronics products industries and many other industrial products from many companies in Latin America (Lora, 2007). For some analysts, this fear of Chinese competition is so big that it may put in jeopardy the future for manufacturing in Latin America (Mesquita Moreira, 2007).

These fears of Asian competition focus on the product dimension of international trade. However, an increasing number of empirical papers show that competition does not take place between industries or products, but within products, i.e. across varieties of vertically differentiated products (qualities). For example, China does not specialize in a limited range of products in line with their relative endowments, but on the contrary offers a very wide range of products.

Today one observes that countries at different levels of development specialise and compete internationally in product varieties at dissimilar prices. At the detailed product level, large and systematic differences in unit values are witnessed, which are proven to be related to differences in factor endowments and development levels. These findings complement the "old" trade theories, which predict that export specialisation across products is relative

\footnotetext{
- ECLAC, United Nations, nanno.MULDER@cepal.org

`CES - Université de Paris 1, rodrigo.paillacar@gmail.com

CEPII, soledad.zignago@cepii.fr

${ }^{1}$ The authors thank Agnès Bénassy, Matthieu Crozet, René Hernandez, José Luis Machinea and Cecilia Vera for their useful comments. An earlier version of this document has been used for the preparation of following publication: ECLAC (2008), "Structural Change and Productivity Growth, 20 Years Later. Old problems, new opportunities", Santiago. The opinions expressed in this document are those of the authors and do not necessarily reflect the views of the ECLAC or CEPII.
} 
endowment-driven. Moreover, the new results also enrich the "new" trade theories, which explain that different countries specialize in different industries, while similar countries specialize in different varieties of similar products shipped at the same price. In sum, the thinking and analysis about international specialization should move away from industries and products towards varieties within products.

In this "new" context, two related strands of literature have emerged in the study of international trade patterns. The first analyses trade at the variety level. Feenstra and Kee (2007) studied the expansion of the number of varieties exported by China and Mexico to the United States during the 1990 to 2001 period. They found that "despite the expansion in Mexican export varieties across all industries, China caught up (i.e. a higher growth rate in the number of varieties) in those cases where Mexico led in 1990 (e.g. Electronics)" (p.14). Other papers use unit values to analyze the product differentiation at the variety level. Schott (2004) found that the US imports exhibit a large variance in unit values within the same product categories. $\mathrm{Xu}$ and $\mathrm{Lu}(2009)$ propose a new measure of export variety that combines unit values with levels of product sophistication (based on Hausmann, Hwang and Rodrik, 2007). Fontagné, Gaulier and Zignago (2008) explore several dimensions of variations in unit values in trade among advanced ("North") and developing countries ("South"). They find that, although the North and South often export similar types of products, they compete in different quality segments.

The second group of papers focuses on possible links between technology-content and export performance. The argument is that understanding variations in export performance requires more than looking at factor endowments alone. That is, other approaches are needed, focusing on technological capabilities (Lall, 2000) and learning, which is part of Schumpeterian and evolutionary economics (Kaplinsky and Santos Paulino, 2005). These authors stress the heterogeneity among countries in terms of technology-content of their exports, using (sometimes arbitrary) classifications. Recently, more elaborated approaches have emerged using measures of export sophistication or "flexibility of countries' export baskets" (Rodrik, 2006; Hausmann et al., 2007a; Hausmann, Rodríguez and Wagner, 2007; Schott, 2008).

These new findings have important consequences for the analysis of the transformation and diversification of Latin American exports and their international competitors. Firstly, the classical view on the upgrading and incorporation of value added in exports was that countries should move away from natural-resource based and low-tech products towards medium and high-tech manufactures. Under the new paradigm, specialisation and value-added incorporation can also take place within the same product (even resource based ones) in a process of vertical differentiation and quality upgrading. ${ }^{2}$ The available gap for export upgrading through quality increases would be given by the relative position of Latin America in quality segments of different products exported.

\footnotetext{
${ }^{2}$ Of course, the potential for incorporating knowledge and value added differs across products. Each product has its own "technological and productive frontier", and countries may need to "jump to another tree" to increase productivity levels (Hausmann and Klinger, 2007).
} 
Secondly, this new paradigm of specialisation within products changes the analysis of trade competition between Latin America and the Caribbean (LAC) and other developing regions, in particular Asia. Today Brazil, Central America and Mexico seem to compete on a wide range of manufactures with China and other Asian countries. Both China and Latin America have expanded the range of manufactures exported. ${ }^{3}$ However, if varieties exported by Latin America and China are different (as suggested by their very different unit values), the risk of direct competition is substantially reduced. If, on the contrary, both continents compete in the same quality segments, LAC would need to accelerate its move up the quality ladder within products as it has no cost advantage over Asia. This means the region would need to step up its innovation efforts in products and processes. Instead of producing a low value-added good with inputs of unskilled workers, capital and raw materials, what is needed now is a combination of highly skilled designers, market analysts, engineers, logistics etc. to improve the quality and sales of its products.

The present paper contrasts the export performances of Latin American-Caribbean and Asia. In particular, we look at the extent to which each region is positioned in different quality segments. As in Fontagné et al. (2008), we analyse export performances in high, medium and low quality segments at the most detailed product-level, but instead of North-South trade, the focus here is on Latin America and the Caribbean and Asia. In addition, we use the Lall's (2000) technology-content classification, as the potential for product differentiation depends on this technology dimension. Until recently, export quality could not be analysed because no database existed including all countries of the world. Our database, BACI, was specifically designed for these types of questions.

Our main hypothesis is that Latin America-Caribbean and Asia compete in different quality segments, as the above mentioned studies suggest that income per capita levels are a major determinant of quality competition, and in this respect both regions differ substantially. The comparison of specialization patterns in quality segments is most interesting in the medium and high-tech sectors, which has the biggest scope for price and quality differentiation.

Our main findings point to an important role for specialisation inside varieties to explain the international market positioning of Latin America and Asia. The evidence suggests that most LAC countries are competing partially with Chinese varieties, and quite directly with products sold abroad by India and other Asian countries. We also find important differences across destination markets and important heterogeneity among LAC countries in terms of positioning, market share evolutions and exposition to low-priced variety competition. Finally, our econometric analyses confirms that unit values of LAC and of Asian exports depend positively on income per capita levels of trading partners, and negatively on the distance between them and the technological content of products being exported.

\footnotetext{
${ }^{3}$ Fontagné and Paillacar (2007) show how many out of the 4,474 manufactures (6 digits codes of the Harmonised System) are exported by emerging countries to the United States: in 1995 China exported 3,485, India 2,861, Brazil 2,299, Mexico 3,805, and Argentina 1,335 products. In 2004, the number of products increased in China (3,941), India $(3,598)$, Brazil $(2,973)$ and Argentina 2,112, whereas it fell in Mexico $(3,730)$. By comparison, in 2004 Germany exported 3,910 products to the United States.
} 
The paper proceeds as follows. In section 2 we describe the methodology and dataset used in this paper. Section 3 illustrates the export market positioning by quality segments and technology categories of both regions. In the section 4, we assess the overlap of export structures in terms of products, quality segments and destination markets. Section 5 examines the dynamics of relative prices of exported varieties. In section 6 we test what are the main determinants of export unit values of Latin America and Asia. Section 7 concludes.

\section{TRADE DATA AND METHODS}

There is a renewed interest in studying the role of prices in international trade for two reasons. First, new theories focus on trade in varieties, unit values, differentiation, and technology content, among others. Second, new highly disaggregated datasets have become available that allow much more refined analyses. In this paper we use BACI, a novel database developed by Gaulier and Zignago (2009), which reconciles detailed United Nations' COMTRADE data on exports and imports with the aim to provide consistent figures for trade values and quantities (and unit-values) for more than 200 countries. Precisely, we use in this work the version of BACI available at the 6-digits of the Harmonised System (HS6), version 1992, disaggregated into 5,000 products, for the period 1995 to 2004 . $^{4}$ BACI is well suited to study trade in varieties, because it provides consistent unit values at the product level. ${ }^{5}$

In this work, we classify each bilateral flow into three quality segments (low, medium or high) by comparing its unit value with the world distribution of unit values of the product following the Fontagné et al. (2008) two-step methodology. Firstly, for each HS6 product, we compute the ratio $(r)$ between the bilateral unit value and the weighted (geometric) average of all unit values in the world. Secondly, if $r<1$ the value of the bilateral flow is divided into low and medium ranges as follows: the share of low range is $\left(1-r^{\alpha}\right)$ and the share in medium range is the complement $\left(r^{\alpha}\right)$, where $\alpha$ regulates the smoothness of the market segment allocation function and is set at 4 to have around the same value in average in each range for total trade in all products. If $r>1$ then the bilateral value is divided into high and medium ranges as follows: share in top range is $\left(1-1 / r^{\alpha}\right)$, and share in medium range is $\left(1 / r^{\alpha}\right)$. Finally, if $r=1$ the whole flow is ascribed to medium range. ${ }^{6}$ In the next section we analyse world market shares across these market segments.

\footnotetext{
${ }^{4}$ BACI (Base pour l'Analyse du Commerce International) was developed at the Centre for International Economics (CEPII) and is available online for COMTRADE users at: http://www.cepii.fr/anglaisgraph/bdd/baci.htm In this work, we exclude the six following chapters of the Harmonized System: mineral products (chapters 25, 26 and 27), works of art, collectors' pieces and antiques (chapter 97) and the two last chapters, 98 and 99, dedicated to special classifications or transactions.

5 Previously, no such reconciled trade unit-values were available. However, unit values could not be calculated beyond 2004, because of a new treatment of quantities in COMTRADE.

${ }^{6}$ This procedure prevents that a small variation in the unit-values evolution for an exporter near of the threshold separating two quality ranges leads to a change in its quality positioning.
} 
This paper also considers a complementary product dimension, which is the technology content of the product being traded. This is because the scope for quality differentiation increases with the technology content. For this purpose, we use the Lall (2000) classification with the following product categories (with acronyms in parentheses): high-tech manufactures ("HT"), medium-tech manufactures ("MT"), low-tech manufactures ("LT"), resource-based manufactures ("RB") and primary products ("PP"). ${ }^{7}$ A novelty of this paper is the analysis of market positioning using a combination of this technology-content classification and price segment dimensions.

The analysis covers trade relations among 94 main economies, representing $90 \%$ of world trade in 2004. Two groups of exporters are considered (Appendix A): (i) Latin America and the Caribbean (LAC), which have broken down by size-geographical location (Brazil, Mexico, Rest of Mercosur, Andean countries, Central America and Caribbean); and (ii) Asia, broken down into China, India and "other Asia", which includes main ASEAN members (Indonesia, Philippines, Singapore, Thailand and Vietnam) and Korea.

\section{WORLD MARKET SHARES BY QUALITY SEGMENTS AND TECHNOLOGICAL CONTENTS}

In this section, we illustrate the competition between LAC and Asia in world trade by looking at world market shares, and their changes in the period 1995-2004, in each of the quality segments and technological content categories.

Firstly, each region has a different technological specialization as shown in Table 1, which gives the world market shares by exporter and technological category in 2004. As expected, Asian exporters have the highest market shares in world trade: $16 \%$ for Asia versus nearly $6 \%$ for LAC. However, LAC has the highest market shares in primary products and a relatively high share in resource-based manufactures (compared to its overall share in world trade, almost 6\%). Asia retains very high market shares in low and high-tech manufactures (in comparison to its total market share). This pattern has not changed very much in the decade of 1995 to 2004, with the exception of China, which has registered extraordinary gains in the high and low technology segments.

\footnotetext{
${ }^{7}$ It should be reminded that we consider a static product classification, which always classifies products as either low (high) tech, even though they may have changed over time to high (low) tech. Some products should be reclassified considering changes in technology. Also, some preliminary evidence suggests that developed countries that used natural resources for their development receive lower prices for exports outside the resource-based sectors.

8 Hausmann and Klinger (2007) have recently proposed an indicator of "product distance", where they reinterpret the revealed comparative advantage in terms of probability that a country can export a good, given the others they are already exporting. They found that Lall and Leamer classifications of exported goods capture some of this "proximity".
} 
Table 1: World market shares by exporter and technology-content category: 2004 levels and period changes

\begin{tabular}{l|rrrrrr|rrrrrr}
\hline & \multicolumn{5}{|c|}{$\mathbf{6 0 0 4}$ levels (\%) } & \multicolumn{5}{c}{$\begin{array}{c}\text { Changes 1995-2004 } \\
\text { (in percentage points) }\end{array}$} \\
\hline & HT & MT & LT & RB & PP & All & HT & MT & LT & RB & PP & All \\
\hline Brazil & 0.4 & 1.0 & 0.8 & 1.6 & 2.4 & 1.2 & 0.21 & 0.17 & -0.05 & -0.25 & 0.53 & 0.12 \\
Mexico & 2.4 & 2.6 & 2.1 & 0.9 & 2.3 & 2.2 & 0.68 & 0.53 & 0.58 & 0.11 & 0.19 & 0.46 \\
Rest of Mercosur & 0.0 & 0.2 & 0.3 & 0.7 & 1.6 & 0.5 & 0.00 & -0.03 & -0.20 & -0.16 & -0.20 & -0.09 \\
Andeans & 0.0 & 0.3 & 0.5 & 2.1 & 4.5 & 1.2 & 0.00 & 0.06 & 0.00 & 0.33 & -0.02 & 0.12 \\
Central America & 0.3 & 0.1 & 0.6 & 0.2 & 0.5 & 0.3 & 0.21 & 0.03 & 0.09 & 0.03 & -0.40 & 0.02 \\
Caribbean & 0.0 & 0.1 & 0.3 & 0.4 & 0.5 & 0.2 & 0.00 & 0.00 & -0.14 & 0.00 & 0.03 & -0.02 \\
\hline TOTAL LAC & $\mathbf{3 . 2}$ & $\mathbf{4 . 4}$ & $\mathbf{4 . 6}$ & $\mathbf{5 . 9}$ & $\mathbf{1 1 . 9}$ & $\mathbf{5 . 5}$ & $\mathbf{1 . 1 1}$ & $\mathbf{0 . 7 6}$ & $\mathbf{0 . 2 9}$ & $\mathbf{0 . 0 7}$ & $\mathbf{0 . 1 3}$ & $\mathbf{0 . 6 1}$ \\
\hline China & 11.7 & 4.7 & 16.1 & 3.4 & 1.7 & 7.2 & 9.20 & 2.96 & 5.65 & 1.54 & -0.44 & 3.78 \\
India & 0.3 & 0.5 & 2.4 & 1.9 & 1.1 & 1.1 & 0.19 & 0.26 & 0.66 & 1.37 & -0.03 & 0.43 \\
Other Asia & 13.7 & 6.3 & 7.2 & 7.3 & 4.1 & 7.8 & 1.47 & 1.61 & -0.99 & 1.21 & -1.95 & 0.73 \\
\hline TOTAL Asia & $\mathbf{2 5 . 7}$ & $\mathbf{1 1 . 5}$ & $\mathbf{2 5 . 7}$ & $\mathbf{1 2 . 5}$ & $\mathbf{6 . 9}$ & $\mathbf{1 6 . 1}$ & $\mathbf{1 0 . 8 7}$ & $\mathbf{4 . 8 3}$ & $\mathbf{5 . 3 1}$ & $\mathbf{4 . 1 2}$ & $\mathbf{- 2 . 4 2}$ & $\mathbf{4 . 9 4}$ \\
\hline
\end{tabular}

Note: Authors' calculations using BACI datasets. "HT" refers to high-tech manufactures, "MT" to medium-tech manufactures, "LT" to low-tech manufactures, "RB" to resource-based manufactures; and "PP" to primary products.

Secondly, there are notable differences in terms of specialization in quality segments among countries in the two regions, which seem related in part to their income per capita levels and size of their economy (Table 2). As both regions consist mostly of low and middle income countries, they are mostly positioned in the low and medium quality range segments, as expected. China and other Asian exporters, however, have also substantial market shares in the high quality segment. The presence of the former in the high quality segment may be related to the large size of its economy, having a diversified export base with some firms targeting the high quality range. Between 1995 and 2004, most market shares were gained in the low quality segment, showing that China did not specialize in high quality products. The presence of the other Asian exporters in the high quality segment is linked to the inclusion of South Korea, which is a major producer of high-tech and high quality manufactures.

Thirdly, the analysis over time shows impressive market share gains for Asia, with only modest advances for LAC. From 1995 to 2004, China, and Asia posted large market share increases, especially in the low quality segment, low and high tech products. If we compare changes in LAC market shares by technology categories and quality segments to average changes (all products together), major increases come from high and medium tech products and medium quality exports. Appendix B gives world market shares for each combination technology/quality. A significant part of the market share loss to China in the world trade of low-quality/low-tech goods was incurred by Mexico, and to a lesser extent the rest of Mercosur, Andeans and the Caribbean. In the category of low-quality high tech goods, Chinese gains were at the expense of Japan (-7\%), Asian countries (-6\%), and the United States $(-3 \%)$. Reflecting shifts in its comparative advantages towards manufactures, China 
gained little market share in RB and PP. In contrast, LAC moved somewhat up market in the medium and high quality segments of medium and high tech products, although it retained the largest absolute shares in primary products.

Table 2: World market shares by exporter and quality segment: 2004 levels and period changes

\begin{tabular}{lccc|ccc}
\hline & \multicolumn{3}{c|}{ 2004 levels (\%) } & \multicolumn{3}{c}{$\begin{array}{c}\text { Changes 1995-2004 } \\
\text { (in percentage points) }\end{array}$} \\
\hline Brazil & Low & Medium & High & Low & Medium & High \\
Mexico & 1.6 & 1.3 & 0.5 & 0.40 & 0.00 & -0.01 \\
Rest of Mercosur & 3.1 & 2.3 & 1.1 & 0.09 & 0.63 & 0.62 \\
Andeans & 0.5 & 0.6 & 0.3 & -0.11 & -0.05 & -0.10 \\
Central America & 1.2 & 1.8 & 0.6 & 0.12 & 0.25 & 0.01 \\
Caribbean & 0.4 & 0.2 & 0.3 & 0.04 & -0.10 & 0.12 \\
TOTAL LAC & 0.3 & 0.3 & 0.1 & -0.02 & 0.01 & -0.06 \\
China & $\mathbf{7 . 1}$ & $\mathbf{6 . 5}$ & $\mathbf{3 . 0}$ & $\mathbf{0 . 5 3}$ & $\mathbf{0 . 7 4}$ & $\mathbf{0 . 5 8}$ \\
India & 13.6 & 5.3 & 2.7 & 7.22 & 2.51 & 1.61 \\
Other Asia & 1.6 & 0.9 & 0.7 & 0.62 & 0.26 & 0.42 \\
TOTAL Asia & 7.8 & 8.3 & 7.5 & -0.77 & 1.62 & 1.18 \\
\hline
\end{tabular}

Note: Authors' calculations using BACI datasets.

Fourthly, LAC's progress in the world trade of high-quality goods is largely accounted for by Mexico. In contrast, Brazil advanced most in the low quality segment, while the rest of the continent shows mixed trends between 1995 and 2004 (Table 2). Mexico withdrew from the low-quality segment and gained market share in the medium and high-quality segments. ${ }^{10}$ Tendencies for Brazil are mixed, as it lost market shares in medium and high-quality segments of low and medium tech goods, but gained in the same segments of HT and

\footnotetext{
9 Chinese comparative advantages changed from agricultural production to manufacturing. Hanson and Robertson (2006) recall that a negative impact of Chinese exports on LAC exports of manufactures will in part be compensated by increases in Chinese imports of PP and RB, which benefits LAC. In another study (Hanson and Robertson, 2008), they show that Chinese export capacity is less important in RB sectors. Both studies do not explore PP Chinese exports.

Results for the medium-quality segment are available upon request from the authors. These gains of Mexico in the period 1995 to 2004 largely correspond to the benefits of NAFTA which was introduced in 1994. NAFTA led to a wave of foreign (mostly US) direct investment in automotive industries and parts and electronics. Although these goods are considered medium and high tech, the production of these goods in Mexico mostly uses cheap unskilled labour, whereas the more sophisticated parts of production (design, R\&D) have remained in the United States and other advanced countries. Another complementary explanation is the product cycle. Vehicles and Hi-tech are still produced by developed countries, which continue to innovate and having higher prices. Exit in low tech sectors (Textiles) for developed countries seems to be high and potentially due to the impossibility to escape to competition by innovating (Lu, 2007; Cadot, Carrère and Strauss-Kahn 2007). As China enters this industry, the price distribution shifted to the left.
} 
especially PP. ${ }^{11}$ Brazil also increased in market share in low-quality PP. Andean countries moved up market, by reducing their market share in the low-quality segment and increasing it in the medium and upper segments. The Rest of Mercosur worsened its performance, losing market shares in almost all technology-content categories and segments. ${ }^{12}$ For Central America, the most notable - albeit small - changes are a withdrawal from the low- and medium-quality segment of PP and a gain in the upper-quality segment of HT. The Caribbean experienced minor gains and losses in all segments and technology-content categories.

Differences in market positioning between Latin America and Asia also stand out when looking at the three main export markets (United States, European Union and Japan) separately. This is illustrated by comparing the quality composition of exports of the two main exporters of each region (Mexico and China) in 2004 (Figure 1). Exports are broken by quality segment and technology intensity.

Mexico and China show notable differences according to destination markets. Chinese exports to all three markets are concentrated in the low-quality range, whereas Mexico's positioning differs: its exports to the United States are mostly of a low-medium quality character, whereas it sells products of a medium-high quality character to the European Union and Japan. In a nutshell, destination markets offer different opportunities. LAC countries, as well Asian exporters, sold at higher prices in the European and especially the Japanese market than the US market.

\section{SIMILARITY OF EXPORT STRUCTURES}

For a deeper understanding of the extent to which LAC and Asia compete directly with each other, we need to look at the overlap of export structures in terms of products, quality segments and destination markets. This overlap, or export similarity, illustrates the extent to which countries compete directly with each other. A rise in the market share of Asian exporters not necessarily hurts LAC if each region's exports are concentrated in different quality segments. In other words, the degree of competition depends on the extent to which countries are exporting the same varieties of products to the same destination markets.

\footnotetext{
${ }^{11}$ Brazil gained market shares in the medium and high quality segments of HT products.

12 A carefully study at the product level could be considered to better understand what drives this loss in competitiveness of the rest of Mercosur: this trading block (except Brazil) lost market shares, and sometimes even regressed to lower quality segments. For example, in the case of Argentina, what has been the impact of the large depreciation of its currency in 2002 on the unit values of its products? When currencies are undervalued, unit values will be comparatively lower: separating exchange rate distortions from real quality differences is difficult because cross-country variations in quality-adjusted prices are unobservable (Hallak and Schott, 2005).

${ }^{13}$ Resource-based manufactures and primary products were excluded because they represent minor share of Chinese and Mexican exports.
} 
Figure 1: Quality composition of exports to main export markets, 2004 (\% share of each quality segment in exports to each destination market)

\section{(a) United States}

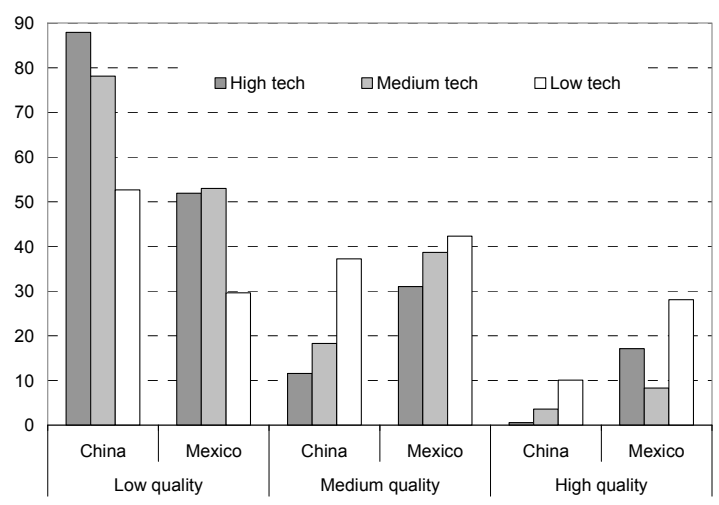

(b) European Union (25)

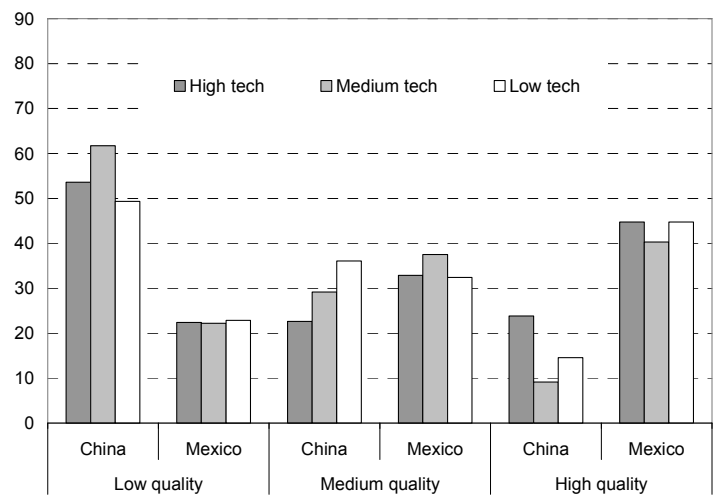

(c) Japan

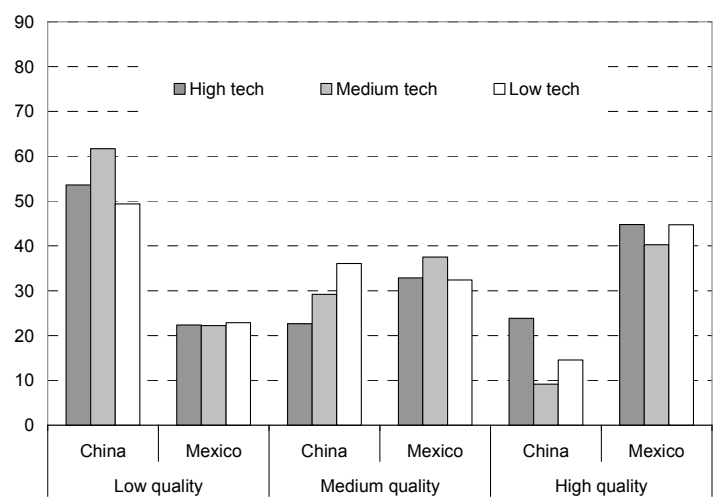

Note: Authors' calculations using BACI datasets. This figure should be read as follows: the first bar in Figure 1(a) shows, for example, that almost $90 \%$ of the Chinese exports of high-tech products to the United States were of low quality. 
We compute this similarity of export structures as one minus half the sum of the absolute value of the differences between the sectoral (or product or variety) shares in manufacturing exports of each country ( 1 is perfect similarity). This indicator is measured at two levels of sectoral aggregation: product (using the 6 digits Harmonised System 92 classification) and variety (separated in the three quality segments). A high degree of similarity at the variety level suggests strong competition among exporters, as they not only produce the same products, but also the same type of variety (quality).

The comparison of export structures in terms of products shows that, within LAC, only Mexico, and to a lesser extent Brazil, had substantial overlap with Asia in 2004 (Table 3). The export structures of Mexico and China were most similar (0.37), followed by Mexico and Asia (0.29). The index of Brazil's bilateral relationship with Asia had a moderate level (above 0.2 ). The rest of LAC exported very different product baskets compared to Asia as expressed by the low value of the index.

The overlap of export structures between LAC and Asia in terms of varieties was considerably less than that in terms of products. This means that both regions are, in part, specialized in different quality segments of the same products. This is most evident in the comparison of Mexico with China, (index drops from 0.37 to 0.24 ) and Mexico with Asia. In the comparison of Brazil with Asia, the index also drops when we move from the product to the variety level. ${ }^{14}$

\section{RELATIVE PRICES OF LATIN AMERICAN EXPORTS}

Another way to assess the differences between the two regions in specialization across varieties within products is to examine the dynamics of relative prices of exported varieties. Relative prices are estimated using bilateral export unit-value ratios to each destination market at the HS6 level. This indicator can shed light on relative prices between two exporters, for a given good shipped to the same destination market. We aggregate such information for each pair of countries, using a weighted median ${ }^{15}$, in order to examine the evolution of the price gap between LAC and Asian countries. If $j$ is the destination market, the bilateral unit-value ratio (UVR) between exporters $A$ and $B$ is:

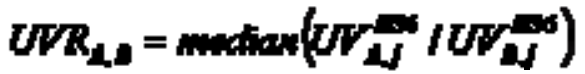

\footnotetext{
${ }^{14}$ Competitive pressures seem to have been relatively stable over time. A comparison of the overlap between 1995 and 2004 at the variety level shows that the value of the index increased little, except for a few cases like Mexico-India, and Brazil-Rest of Mercosur with India (see the Appendix C).

${ }^{15}$ The weight is $w=0.5\left(V_{A, j}^{H S 6} / V_{A}+V_{B, j}^{H S 6} / V_{B}\right)$, where $V_{A}$ and $V_{B}$ are the total exports of (groups of) countries A and B. Note that grouping exporters has shortcomings, because unit values and HS6 product weights may differ strongly among countries, making it difficult to determine what specific nations are driving the unit value attributed to the entire group. Nevertheless, using the median can mitigate this problem and the impact of outliers, and the weight warrants that the more relevant countries and products are taking into account.
} 
Table 3: Latin America and Asia: export similarities at the product and variety level, 2004

\begin{tabular}{|c|c|c|c|c|c|c|c|c|}
\hline & Brazil & Mexico & $\begin{array}{c}\text { Rest of } \\
\text { Mercosur }\end{array}$ & Andeans & $\begin{array}{l}\text { Central } \\
\text { America }\end{array}$ & Caribbean & China & India \\
\hline & \multicolumn{8}{|c|}{ Product Level } \\
\hline Brazil & & & & & & & & \\
\hline Mexico & 0.28 & & & & & & & \\
\hline Rest of Mercosur & 0.25 & 0.13 & & & & & & \\
\hline Andeans & 0.18 & 0.12 & 0.14 & & & & & \\
\hline Central America & 0.14 & 0.15 & 0.11 & 0.12 & & & & \\
\hline Caribbean & 0.08 & 0.08 & 0.05 & 0.07 & 0.10 & & & \\
\hline China & 0.21 & 0.37 & 0.09 & 0.11 & 0.17 & 0.08 & & \\
\hline India & 0.26 & 0.21 & 0.15 & 0.14 & 0.16 & 0.08 & 0.30 & \\
\hline \multirow[t]{2}{*}{ Other Asia } & 0.21 & 0.29 & 0.10 & 0.11 & 0.15 & 0.06 & 0.39 & 0.23 \\
\hline & \multicolumn{8}{|c|}{ Variety Level } \\
\hline Brazil & . & & & & & & & \\
\hline Mexico & 0.22 & . & & & & & & \\
\hline Rest of Mercosur & 0.21 & 0.11 & . & & & & & \\
\hline Andeans & 0.15 & 0.10 & 0.12 & . & & & & \\
\hline Central America & 0.11 & 0.10 & 0.09 & 0.09 & . & & & \\
\hline Caribbean & 0.06 & 0.06 & 0.04 & 0.05 & 0.07 & . & & \\
\hline China & 0.17 & 0.24 & 0.07 & 0.08 & 0.13 & 0.05 & . & \\
\hline India & 0.23 & 0.23 & 0.17 & 0.14 & 0.15 & 0.10 & 0.23 & . \\
\hline Other Asia & 0.19 & 0.22 & 0.09 & 0.09 & 0.11 & 0.05 & 0.26 & 0.20 \\
\hline
\end{tabular}

Note: Authors' calculations using BACI datasets. Similarity between country A (column) and B (row) is one minus half the sum of the absolute value of differences between the (e.g.) sectoral shares in manufacturing exports of country A and those of country B. It ranges between 0 (perfect dissimilarity) and 1 (perfect similarity). Figures in bold indicate similarities above the mean.

This indicator is calculated for all technology-content categories. Unsurprisingly, developed countries charged higher export prices than LAC countries, often more than $50 \%$, and in many cases more than $100 \%$ (results not reported here). Figure 2 shows that the unit value gap with developed countries is however smaller for primary and resource-based products (about $31 \%$ in average), than for technological products (about $60 \%$ in average). ${ }^{16}$ Moreover, ratios are close to (or even below) one for the natural resource-intensive countries (Australia, New Zealand and Canada).

\footnotetext{
${ }^{16}$ One has to bear in mind that an apparently small unit value gap of $31 \%$ is a non negligible space for LAC to climb the quality ladder as PP and RB together accounted for more than 70\% of South American exports in 2004. Moreover, the average price gap of $31 \%$ hides a large heterogeneity. For example, the price gap with Japan is more than $70 \%$.
} 
Figure 2: Median unit value ratios observed at the product level (2004) LAC low (high) income vs. other countries

\section{UVRs for natural resource based products}

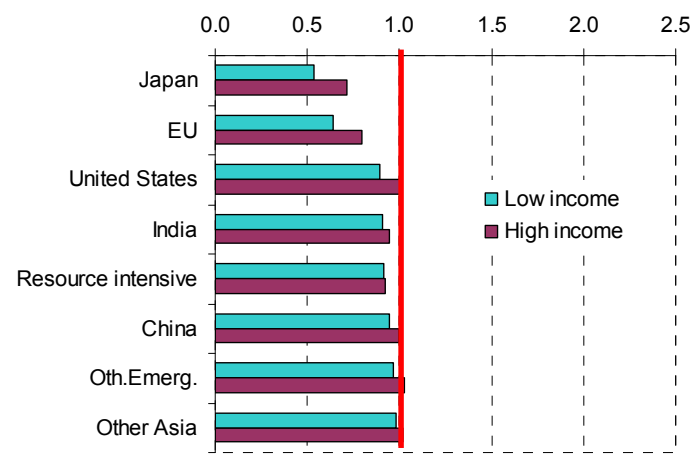

UVRs for high-tech products

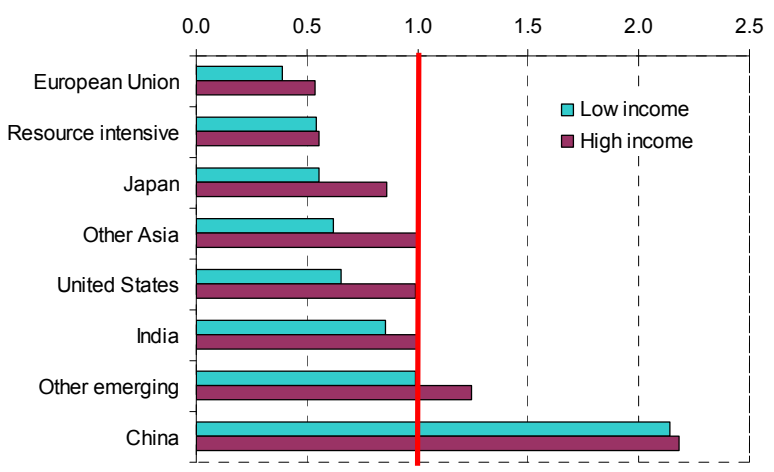

Note: Authors' calculations using BACI datasets. Each bar represents the ratio of the unit value of LAC low (high) income exports to the unit value of exporters on the vertical axis. Resource intensive countries are Australia, New-Zealand and Canada.

Figure 3 shows that unit values of LAC differed considerably from those of China in 2004, but much less so from India and other Asia. On average, the unit value of Chinese exports was 0.78 that of LAC countries (except for PP and RB), while prices of Asian exports seem to be similar to those of LAC. This result is consistent with the efforts of Asian Tigers to move from low- to the medium-quality segments.

Within Latin America, income per capita levels seem to be an important determinant of relative price performance in LAC, except for primary products (Figure 3). High-income LAC tend to sell at better prices (UVRs close to 1) than low-income countries in the region, particularly for MT and HT products. However, the income-level and UVR relation is not always monotonic for medium income levels. Moreover, for primary products there are no clear differences between high and low-income LAC exporters.

Unit values of East Asia (without China) and LAC (Brazil, Mexico, and Central America) are relatively similar. But supply capacities of LAC countries seem constrained, and not always able to follow the pace of world market demand. Many reasons can explain this situation, like credit constraints for exports, a lack of innovative efforts and human capital to produce certain goods (see Hausmann and Klinger, 2007).

\footnotetext{
${ }^{17}$ UVRs of primary products seemed less related to income levels, as UVRs with resource-intensive countries were almost identical for all LAC per capita income groups. More differences can be found by geographic groups: Central American prices were $21 \%$ below those of developed natural resource intensive countries, those of the Caribbean $10 \%$ better and the rest around 10\% lower. These differences are not surprising considering that natural endowments are strong determinants of competitiveness for these groups, and geography is highly correlated with endowments.
} 
Figure 3: Median unit value ratios at the product level, 1995 and 2004, in world markets (Other countries/regions as a ratio of $L A C$ )

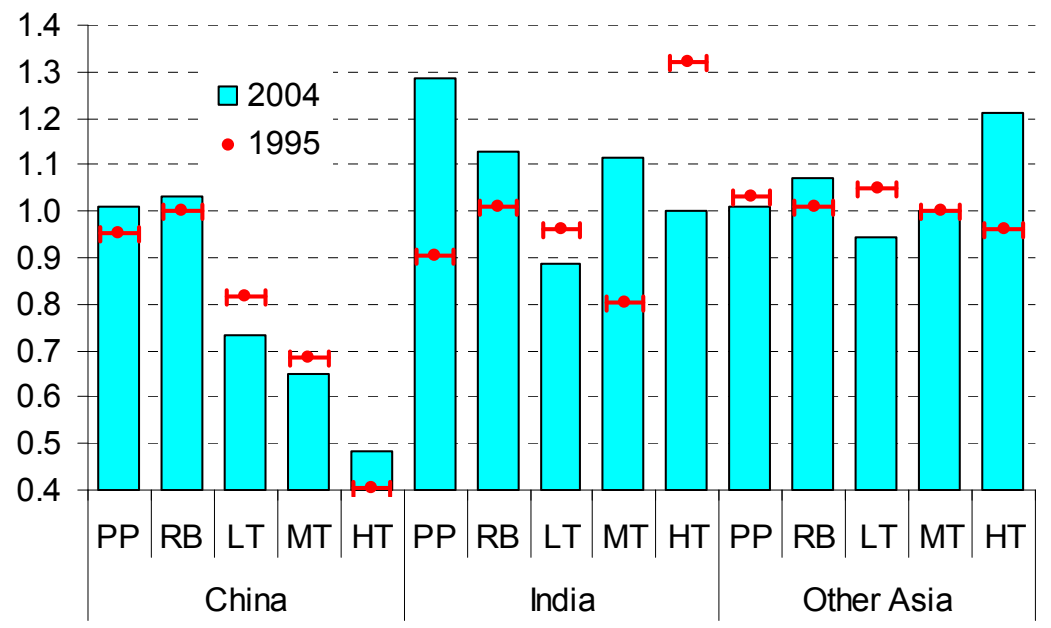

Notes: Authors' calculations using BACI datasets. Each figure represents the median ratio of Chinese, Indian and other Asian exporters to the unit values of total LAC. "HT" refers to high-tech manufactures, "MT" to medium-tech manufactures, "LT" to low-tech manufactures, "RB" to resource-based manufactures; and "PP" to primary products.

\section{DETERMINANTS OF MARKET POSITIONING IN TERMS OF UNIT VALUES: AN ECONOMETRIC ANALYSIS}

Export unit values tend to depend on the level of development of both the exporter and the importer. This relationship is best observed for differentiated products (mostly in the medium and high-tech categories), where more advanced countries produce high quality varieties with production processes intensive in $\mathrm{R} \& \mathrm{D}$ and skilled labour. These relationships were tested by Schott (2004) focusing on US imports of manufactures that are produced simultaneously and significantly in the North and South. Fontagné et al. (2008) extended his analysis to world imports, focusing in particular to the EU, Japanese and US markets, and using the same detailed database and period as this paper. They found that unit values of imported products are positively related to the income per capita of the exporter and the importer. Moreover, they estimated that import unit values increase with the distance separating trading partners, which confirms the Alchian-Allen conjecture: if transport costs have a fixed component bilateral distance should be less relevant for higher-quality products, leading to "shipping the good apples out" (Hummels and Skiba, 2004).

Our aim in this section is to analyse the determinants of export prices of LAC and Asian countries. In Table 5, we run in the first column exactly the same estimation as Fontagné et al. (2008) for world imports, with the only difference that here we consider all products, including thus primary products and all manufactures (even those that are not exchanged 
simultaneously and in substantial amounts by the North and the South). ${ }^{18}$ We obtain almost the same coefficients for exporter and importer GDPs per capita (GDP PC, at purchasing power parity terms) and bilateral distance. A similar regression for Asian exports (including China, column 2) shows the same signs but smaller elasticities for levels of development of the exporter and importer but a larger one for distance.

Table 5: Explanation of bilateral unit values by level of development of trading partners and bilateral distance (pooled data), 1995-2004

\begin{tabular}{lccc}
\hline & World & $\begin{array}{c}\text { Asian } \\
\text { exports }\end{array}$ & $\begin{array}{c}\text { Latin American } \\
\text { exports }\end{array}$ \\
\hline Intercept & 0.006 & 0.002 & 0.000 \\
Log Exporter GDP PC & $(0.000)$ & $(0.001)$ & $(0.595)$ \\
& 0.326 & 0.292 & -0.210 \\
Log Importer GDP PC & $(0.000)$ & $(0.000)$ & $(0.000)$ \\
& 0.150 & 0.056 & -0.143 \\
Log bilateral distance & $(0.000)$ & $(0.000)$ & $(0.000)$ \\
& 0.080 & 0.106 & 0.253 \\
No. observations & $(0.000)$ & $(0.000)$ & $(0.000)$ \\
$\mathrm{R}^{2}$ & 26514993 & 3204705 & 1710553 \\
\hline
\end{tabular}

Note: OLS estimations explaining lnUVijkt, where $\mathrm{i}$ (or Exp) is the exporter, $\mathrm{j}$ (or Imp) the importer, k the hs6 product, $t$ the year, UV the unit value, and PCGDP the per capita GDP. We use BACI datasets and take into account $\mathrm{k} * \mathrm{t}$ fixed effects (standard errors in parentheses).

However, the regression for Latin American export unit values (column 3) shows opposite signs with respect to the income level of both trading partners. The negative coefficient suggests that an increase in the level of development of both the importer and exporter has a negative effect on the unit value of exports. To better understand this implausible result, we introduce quadratic terms testing thus a non-linear relationship between income levels and Latin American unit values.

Also, we included the size of the trading partners proxied by the population of both the importer and exporter as determinants. This is because a larger home market, given a certain level of income per capita, provides more scale economies for production and export, and therefore is expected to reduce unit values. By the same token, a larger import market allows for larger import volumes and more competition and therefore lower unit values, as well as lower cost to import (minimum demand size, better trade infrastructures, etc). Baldwin and Ito (2008) run very close specifications but their proxies for the size of the economies are the GDPs.

Finally, we also included dummies in the regression to account for different (unobservable) purchasing behavior of relevant main world import markets for our analysis. The idea is that consumers of different markets may differ in their taste for quality, even if their income per

\footnotetext{
${ }^{18}$ GDP data are also taken from the World Development Indicators (2006) and distances from the CEPII.
} 
capita is similar. The geographical composition of exports of each region may then influence their market positioning in terms of unit values.

Table 6 shows results when we introduce these new explanatory variables in the estimation of unit values exported by all countries of our sample (world exports, first two columns), by Asian countries (columns 3 and 4) and by Latin American countries (last three columns).

Table 6 Explaining bilateral unit values by the level of development (non-linear), size and distance between trading partners (pooled data), 1995-2004

\begin{tabular}{|c|c|c|c|c|c|c|c|}
\hline & World e & xports & Asian e & xports & & C export & \\
\hline Intercept & 0.00 & 0.00 & 0.00 & 0.00 & 0.00 & 0.00 & 0.00 \\
\hline & 0.005 & 0.005 & 0.015 & 0.015 & 0.063 & 0.063 & 0.063 \\
\hline Exp PC GDP & -1.48 & -1.44 & -0.99 & -0.78 & 2.88 & 2.80 & 2.26 \\
\hline & 0.005 & 0.005 & 0.015 & 0.015 & 0.063 & 0.063 & 0.063 \\
\hline$(\operatorname{Exp} P C \text { GDP })^{2}$ & 0.09 & 0.09 & 0.05 & 0.04 & -0.16 & -0.15 & -0.12 \\
\hline & 0.000 & 0.000 & 0.001 & 0.001 & 0.004 & 0.004 & 0.004 \\
\hline Imp PC GDP & -0.79 & -0.26 & 0.66 & 0.49 & 1.16 & -0.50 & -0.47 \\
\hline & 0.004 & 0.004 & 0.011 & 0.013 & 0.016 & 0.022 & 0.022 \\
\hline$(\operatorname{Imp} \text { PC GDP })^{2}$ & 0.05 & 0.02 & -0.03 & -0.02 & -0.06 & 0.03 & 0.03 \\
\hline & 0.000 & 0.000 & 0.001 & 0.001 & 0.001 & 0.001 & 0.001 \\
\hline Exp Population & -0.09 & -0.09 & -0.17 & -0.17 & -0.12 & -0.11 & -0.09 \\
\hline & 0.000 & 0.000 & 0.000 & 0.000 & 0.001 & 0.001 & 0.001 \\
\hline Imp Population & -0.02 & -0.01 & 0.04 & 0.03 & -0.05 & -0.04 & -0.04 \\
\hline & 0.000 & 0.000 & 0.000 & 0.000 & 0.000 & 0.001 & 0.001 \\
\hline Distance & 0.10 & 0.13 & 0.05 & 0.13 & 0.21 & 0.25 & 0.18 \\
\hline & 0.000 & 0.000 & 0.000 & 0.001 & 0.001 & 0.001 & 0.001 \\
\hline US imports & & -0.07 & & -0.13 & & 0.01 & -0.01 \\
\hline & & 0.001 & & 0.002 & & 0.003 & 0.003 \\
\hline EU imports & & 0.11 & & 0.17 & & 0.16 & 0.15 \\
\hline & & 0.000 & & 0.001 & & 0.002 & 0.002 \\
\hline Japanese imports & & 0.32 & & 0.33 & & 0.20 & 0.22 \\
\hline & & 0.001 & & 0.002 & & 0.004 & 0.004 \\
\hline Asian imports & & 0.05 & & 0.09 & & 0.15 & 0.18 \\
\hline & & 0.001 & & 0.002 & & 0.003 & 0.003 \\
\hline LAC imports & & -0.49 & & -0.41 & & 0.39 & 0.28 \\
\hline & & 0.001 & & 0.003 & & 0.003 & 0.003 \\
\hline Mexican exports & & & & & & & -0.22 \\
\hline & & & & & & & 0.002 \\
\hline No. obs. & $57,193,219$ & $57,193,219$ & $6,335,447$ & $6,335,447$ & $3,211,020$ & $3,211,020$ & $3,211,020$ \\
\hline $\mathrm{R}^{2}$ & 0.0609 & 0.0805 & 0.0822 & 0.106 & 0.045 & 0.0531 & 0.0578 \\
\hline
\end{tabular}

Note: OLS estimations explaining lnUVijkt, where i (or Exp) is the exporter, $\mathrm{j}$ (or Imp) the importer, k the hs6 product, $\mathrm{t}$ the year, UV the unit value, and PCGDP the per capita GDP. We use BACI datasets and take into account $\mathrm{k} * \mathrm{t}$ fixed effects (standard errors in italics). 
Several results stand out. Firstly, they confirm the non-linear relationship between per capita incomes and unit values. At the world level, this relationship seems to be negative at low levels of income per capita of both exporters and importers, but turns positive at higher levels of development. The coefficients on the exporter income per capita remain different for LAC compared to Asia, which are close to those obtained for the world. This different result for LAC compared to Asia and the world may be related to the high share of primary products and resource based manufactures in LAC exports, which may exhibit a different relationship with level of development. Even if we introduce product*year fixed effects in our estimations, the pooled result is probably reflecting the weight of primary products and resource based manufactures in Latin American exports. However, the sign of the importer income is now the same between LAC and Asian exports, suggesting that world results are maybe reflecting more developed exports behaviour.

Secondly, results on dummies for specific markets are highly significant and suggest that the US tends to import cheaper goods than the EU, Japan and Asian countries. Regarding Latin American exports, results confirm findings of our descriptive analysis: US imports have no impact on LAC export unit-values, whereas European and Japanese imports exert a strong positive influence on these unit values. This positive impact is even stronger for LAC imports, whereas the impact is hardly negative for LAC imports from all exporters in the world (column 2). In other words, the LAC demand contributes negatively to world and Asian prices but positively to LAC prices, as LAC may be a regional platform for more differentiated and high-quality products. In the last column, we included a dummy for Mexico as an exporter, which shows that this country impacts Latin American unit values negatively. This may illustrate the so called maquila "model" of Mexican export production, which emphasises low-costs.

Thirdly, based on the recent literature on heterogeneous firms trade Baldwin and Ito (2008) classify exports by quality and price competition, for a given pair product*exporter. Precisely, these authors run similar estimations as in Table 6, but instead by pooling data for each HS6 product and interpret the sign of the distance variable in terms of quality $(+)$ or price $(-)$ competition. Appendix D gives the distribution of the estimated coefficients on bilateral distance for global, Asian and LAC exports. In these histograms, we plot only significant coefficients. The median (significant) elasticity of distance for Asian exports (0.16) is close to the world median (0.12), but much below the median for Latin American exports (0.37). This suggests that for Asian exporters, competition on prices is important in more cases (or products*years) than for Latin America which competes more on quality.

Finally, we disaggregated total Latin American exports by the different Lall's categories of products. Table 7 confirms that the previously tested relationships differ according the technological intensity of products. In particular, the coefficients for income per capita of the exporter and importer turn from negative to positive as the technology intensity increases, whereas the opposite occurs for the square of this variable. The variables population and distance maintain their expected relationship throughout the different Lall categories. 
Table 7: Explaining bilateral unit values by the level of development (non-linear), size and distance between trading partners (pooled data), by technology intensity category 1995-2004

\begin{tabular}{|c|c|c|c|c|c|c|c|c|c|c|}
\hline \multirow[b]{2}{*}{ Intercept } & \multicolumn{2}{|c|}{$\begin{array}{l}\text { Primary } \\
\text { products }\end{array}$} & \multicolumn{2}{|c|}{$\begin{array}{l}\text { Resource- } \\
\text { based } \\
\text { products }\end{array}$} & \multicolumn{2}{|c|}{$\begin{array}{l}\text { Low tech } \\
\text { products }\end{array}$} & \multicolumn{2}{|c|}{$\begin{array}{l}\text { Medium tech } \\
\text { products }\end{array}$} & \multicolumn{2}{|c|}{$\begin{array}{l}\text { High tech } \\
\text { products }\end{array}$} \\
\hline & 0.00 & 0.585 & 0.00 & 0.812 & 0.00 & 0.969 & 0.00 & 0.823 & 0.00 & 0.9409 \\
\hline $\operatorname{Exp} P C G D P$ & -1.59 & $(0.000)$ & -4.51 & $(0.000)$ & 1.10 & $(0.0$ & 3.48 & $(0.000)$ & 21.83 & $(0.000)$ \\
\hline$(\operatorname{Exp} P C G D P)^{2}$ & 0.10 & $(0.000)$ & 0.26 & $(0.000)$ & -0.05 & $(0.000)$ & -0.19 & $(0.000)$ & -1.27 & $(0.000)$ \\
\hline Imp $P C G D P$ & -0.92 & $(0.000)$ & 0.41 & $(0.000)$ & 1.43 & $(0.000)$ & 1.44 & $(0.000)$ & 2.35 & $(0.000)$ \\
\hline$(\operatorname{Imp} P C G D P)^{2}$ & 0.06 & $(0.000)$ & -0.02 & $(0.000)$ & -0.08 & $(0.000)$ & -0.08 & $(0.000)$ & -0.13 & $(0.000)$ \\
\hline Exp Population & -0.04 & & -0.02 & $(0.0$ & -0.07 & (0. & -0.14 & (0. & -0.49 & $(0.000)$ \\
\hline Exp Population & -0.03 & & -0.01 & $(0.0$ & -0.02 & & -0.03 & $(0$. & -0.06 & $(0$. \\
\hline Distance & 0.02 & $(0.000)$ & -0.02 & $(0.000)$ & 0.18 & $(0.000)$ & 0.16 & $(0.000)$ & 0.98 & $(0.000)$ \\
\hline No. obs. & & 269934 & & 623276 & & 071591 & & 876424 & & 327153 \\
\hline $\mathrm{R}^{2}$ & & 0.022 & & 0.009 & & 0.036 & & 0.03 & & 0.324 \\
\hline
\end{tabular}

Note: OLS estimations explaining lnUVijkt, where $\mathrm{i}$ (or Exp) is the exporter, $\mathrm{j}$ (or Imp) the importer, k the hs6 product, $\mathrm{t}$ the year, UV the unit value, and PCGDP the per capita GDP. We use BACI datasets and include $\mathrm{k}^{*} \mathrm{t}$ fixed effects (standard errors in parentheses). "HT" refers to high-tech manufactures, "MT" to medium-tech manufactures, "LT" to low-tech manufactures, "RB" to resource-based manufactures; and "PP" to primary products.

\section{CONCLUSION}

As Fontagné et al. (2008) and Schott (2004), we found that differentiation in varieties is an important feature of international specialization. In general, LAC have succeeded in charging higher prices for its exports than China in manufactures (other than derivatives of natural resources), although LAC prices are similar of those of India and other Asian exporters. The price differences between Latin America and China has increased over time.

From 1995 to 2004, China and other Asia gained large market shares, not only in the low quality segment but also in the high quality segment of medium and high tech products. Chinese gains in low-quality low-tech goods were concomitant with losses of many LAC countries. In contrast, LAC moved somewhat up market in the medium quality segments of medium and high tech products, although it retained the largest absolute shares in primary products.

General results for LAC hide a large diversity among countries in the region. Mexico, Central America, and to some extent Brazil have increased the technology-content of their exports, as well as their positioning in quality segments. However, the export performance in technology products of the rest of South America stagnated. The diverging results between Brazil and the rest of South America call for further comparative analysis of policies, reforms and export trajectories of specific industries. In general, it seems that the emergence of China has mostly affected the LAC exports of low-quality varieties. 
Economic development seems to determine the competitiveness performance: High and medium-high income per capita countries in LAC seem to have made important progress towards better prices in the low, medium and high tech goods, whereas the low income countries in the region regressed in terms of quality segment positioning, without gains in market share.

Econometric tests on the determinants of export unit values of Latin American and Asian products show several interesting results. They confirm a positive but non-linear relationship between income per capita of the exporter and importer on the one hand and unit values on the other. Moreover, results on dummies for specific markets suggest that US imports have no impact on LAC export unit-values, whereas European and Japanese imports exert a strong positive influence on LAC unit values. This positive impact is even stronger for LAC imports. Another interesting result is that Mexico as an exporter impacts Latin American unit values negatively, which may illustrate its so called maquila "model" of export production emphasizing low costs. Finally, the results show that global competition differs between the two regions: prices play a bigger role in the case of Asian exports, whereas Latin America competes more on quality in world markets.

More detailed analysis could be carried out for specific countries and sectors. The evidence presented here shows that Mexico is also the country that succeeded most in upgrading the technology- and quality contents of its exports, even though China and other Asian countries were much more successful. LAC should monitor carefully Asian's recent progress and study how this technology and quality upgrading is being done. 


\section{REFERENCES}

Anderson, J. and E. van Wincoop (2003), "Gravity with Gravitas: A Solution to the Border Puzzle", American Economic Review, 93(1):170-92.

Baldwin, R. and T. Ito (2008), "Quality Competition versus Price Competition Goods: An Empirical Classification”, NBER Working Paper, No. 14305, NBER, Cambridge, MA.

Berthelon, M. and C. Freund (2004), "On the Conservation of Distance in International Trade”, World Bank Policy Research Working Paper 3293.

Cadot, O., C. Carrère and V. Strauss-Kahn (2007), "Export Diversification: What's Behind the Hump?", CEPR Discussion Paper 6590.

Feenstra, R. and H.L. Kee (2007), "Trade Liberalization and Export Variety: A Comparison of Mexico and China", The World Economy, 30(1): Page 5-21.

Feenstra, R., J. Markusen and A. Rose (2001), "Using the Gravity Equation to Differentiate among Alternative Theories of Trade", Canadian Journal of Economics, 34(2): 430-447.

Fontagné, L. G. Gaulier and S. Zignago (2008), "Specialisation across Varieties and NorthSouth Competition", Economic Policy 23(1): 51-91.

Fontagné, L. and R. Paillacar (2007), "China is shipping more products to the United States than Germany", La lettre du CEPII, No. 270.

Gaulier, G. and S. Zignago (2008), "BACI: A World Database of International Trade Analysis at the Product Level", CEPII Working Paper, forthcoming.

Hanson, G. and R. Robertson (2006), "China and the Recent Evolution of Latin America's Manufacturing Exports", in D. Lederman and M. Olarreaga, eds., China's and India's Challenge to Latin America, Washington, DC: The World Bank.

Hanson, G. and R. Robertson (2008), "China and the Manufacturing Exports of Other Developing Countries", NBER Working Paper 14497.

Hausmann, R., J. Hwang and D. Rodrik (2007), "What you Export Matters", Journal of Economic Growth, 12(1): 1-25.

Hausmann, R. and B. Klinger (2007a), "The Structure of the Product Space and the Evolution of Comparative Advantage", CID Working Paper 146, Center for International Development, Harvard University. 
Hausmann, R., F. Rodríguez and R. Wagner (2007b), "Growth Collapses", Wesleyan Economics Working Papers 2006-024, Wesleyan University.

Hallak, J.C. and P. Schott (2008), "Estimating Cross-Country Differences in Product Quality", NBER Working Paper 13807.

Hummels, D. and A. Skiba (2004). 'Shipping the Good Apples Out: An Empirical Confirmation of the Alchian-Allen Conjecture', Journal of Political Economy, 112 (6), December, 1384-1402.

Kaplinsky, R. and A. Santos Paulino (2005), "Innovation and Competitiveness: Trends in Unit Prices in Global Trade", Oxford Development Studies, 33(3-4):333-355.

Lall, S. (2000), “The Technological Structure and Performance of Developing Country Manufactured Exports, 1995-98”, Oxford Development Studies, 28(3):337-369.

Lora, E. (2007), "Should Latin America Fear China?", in Santiso, J. (ed.), The Visible Hand of China in Latin America, Development Centre Studies, Paris.

Lu, Chia-Hui (2007), "Moving Up or Moving Out? A Unified Theory of R\&D, FDI, and Trade", Journal of International Economics, 71(2):324-343.

Mesquita Moreira, M. (2007), "Fear of China: Is There a Future for Manufacturing in Latin America?", World Development, 35(3), 355-376.

Rauch, J. E. (1999), "Networks Versus Markets in International Trade", Journal of International Economics 48(1): 7-35.

Rodrik, R. (2006), "What's So Special About China's Exports?" China \& World Economy, 14(5): 1-19.

Schott P. K. (2004), “Across-Product versus Within-Product Specialization in International Trade", Quarterly Journal of Economics, 119(2): 647-678.

$\mathrm{Xu}, \mathrm{B}$. and J. Lu (2009), "Foreign direct investment, processing trade, and the sophistication of China's exports", China Economic Review, article in press. 


\section{APPENDIX A: GROUPINGS OF COUNTRIES EMPLOYED IN THE ANALYSIS}

\begin{tabular}{|c|c|c|c|c|c|}
\hline (a) & & By per-capita income levels & (b) & & By geographical location \\
\hline No. & Group name & Countries & No. & Group name & Countries \\
\hline \multirow[t]{8}{*}{$\mathrm{i}$} & Low & Bolivia & $\mathrm{i}$ & Brazil & Brazil \\
\hline & & Cuba & ii & Mexico & Mexico \\
\hline & & Ecuador & jiii & Rest Mercosur & Argentina \\
\hline & & Guyana & & & Paraguay \\
\hline & & Haiti & & & Uruguay \\
\hline & & Honduras & iv & Andeans & Bolivia \\
\hline & & Jamaica & & & Chile \\
\hline & & Nicaragua & & & Colombia \\
\hline \multirow[t]{8}{*}{ ii } & Medium-low & Dominica & & & Ecuador \\
\hline & & El Salvador & & & Peru \\
\hline & & Guatemala & & & Venezuela, RB \\
\hline & & Paraguay & $\mathrm{v}$ & Central America & Costa Rica \\
\hline & & Peru & & & El Salvador \\
\hline & & St. Lucia & & & Guatemala \\
\hline & & St. Vincent and the Grenadines & & & Honduras \\
\hline & & Venezuela, RB & & & Nicaragua \\
\hline \multirow[t]{7}{*}{ iii } & $\begin{array}{l}\text { Medium- } \\
\text { high }\end{array}$ & Belize & & & Panama \\
\hline & & Brazil & vi & Caribbean & Belize \\
\hline & & Colombia & & & Cuba \\
\hline & & Dominican Republic & & & Dominica \\
\hline & & Grenada & & & Domincan Republic \\
\hline & & Panama & & & Grenada \\
\hline & & Suriname & & & Guyana \\
\hline \multirow[t]{8}{*}{ iv } & High & Antigua and Barbuda & & & Haiti \\
\hline & & Argentina & & & Jamaica \\
\hline & & Chile & & & St. Kitts and Nevis \\
\hline & & Costa Rica & & & St. Lucia \\
\hline & & Mexico & & & St. Vincent and the Grenadines \\
\hline & & St. Kitts and Nevis & & & \\
\hline & & Trinidad and Tobago & & & Surinam \\
\hline & & Uruguay & & & Trinidad and Tobago \\
\hline $\mathrm{v}$ & Total LAC & All countries & vii & Total LAC & All countries \\
\hline
\end{tabular}


APPENDIX B: EXPORTERS' MARKET SHARES (AS A \% OF WORLD TRADE IN EACH COMBINATION TECHNOLOGY/QUALITY)

\begin{tabular}{|c|c|c|c|c|c|c|c|c|c|c|c|c|}
\hline & \multicolumn{6}{|c|}{2004 levels } & \multicolumn{6}{|c|}{ Changes (1995-2004) } \\
\hline & HT & MT & $\mathbf{L T}$ & RB & $\mathbf{P P}$ & All & $H T$ & $M T$ & $L T$ & $R B$ & $P P$ & All \\
\hline \multicolumn{13}{|l|}{ LOW-QUALITY: } \\
\hline Brazil & 0.3 & 1.8 & 1.1 & 2.3 & 3.4 & 1.6 & 0.0 & 0.6 & 0.1 & 0.1 & 1.2 & 0.4 \\
\hline Mexico & 3.1 & 4.2 & 2.0 & 1.2 & 3.6 & 3.1 & -0.7 & 0.5 & -0.9 & 0.0 & 1.9 & 0.1 \\
\hline Rest of Mercosur & 0.1 & 0.3 & 0.3 & 0.7 & 1.9 & 0.5 & 0.0 & -0.1 & -0.3 & -0.2 & -0.5 & -0.1 \\
\hline Andeans & 0.1 & 0.3 & 0.5 & 2.0 & 5.1 & 1.2 & 0.0 & 0.0 & -0.1 & 0.3 & -0.8 & 0.1 \\
\hline Central America & 0.2 & 0.2 & 1.0 & 0.3 & 0.5 & 0.4 & 0.1 & 0.1 & 0.3 & 0.0 & -0.5 & 0.0 \\
\hline Caribbean & 0.0 & 0.1 & 0.4 & 0.5 & 0.6 & 0.3 & 0.0 & 0.0 & -0.1 & 0.1 & -0.2 & 0.0 \\
\hline Total LAC & 3.9 & 7.0 & 5.1 & 6.8 & 15.0 & 7.1 & -0.6 & 1.0 & -0.9 & 0.3 & 1.2 & 0.5 \\
\hline China & 21.0 & 10.1 & 28.6 & 5.5 & 2.4 & 13.6 & 15.6 & 6.4 & 10.5 & 2.5 & -1.0 & 7.2 \\
\hline India & 0.6 & 0.8 & 3.6 & 3.4 & 1.3 & 1.6 & 0.4 & 0.3 & 1.0 & 2.6 & -0.8 & 0.6 \\
\hline Other Asia & 7.7 & 9.6 & 7.9 & 7.8 & 3.7 & 7.8 & -5.5 & 2.3 & -0.7 & 1.7 & -2.2 & -0.8 \\
\hline Total Asia & 29.2 & 20.5 & 40.1 & 16.6 & 7.5 & 23.0 & 10.4 & 9.0 & 10.8 & 6.8 & -4.0 & 7.1 \\
\hline \multicolumn{13}{|l|}{ MEDIUM-QUALITY: } \\
\hline Brazil & 0.8 & 1.0 & 1.1 & 1.6 & 2.0 & 1.3 & 0.7 & 0.1 & -0.2 & -0.5 & 0.0 & 0.0 \\
\hline Mexico & 3.2 & 2.9 & 2.7 & 0.8 & 1.9 & 2.3 & 2.3 & 1.0 & 1.2 & 0.0 & -0.8 & 0.6 \\
\hline Rest of Mercosur & 0.0 & 0.2 & 0.3 & 0.9 & 1.4 & 0.6 & 0.0 & 0.0 & -0.2 & -0.1 & -0.1 & -0.1 \\
\hline Andeans & 0.0 & 0.4 & 0.5 & 2.9 & 4.6 & 1.8 & 0.0 & 0.1 & 0.0 & 0.5 & 0.2 & 0.2 \\
\hline Central Am & 0.1 & 0.1 & 0.5 & 0.2 & 0.3 & 0.2 & 0.1 & 0.0 & -0.1 & 0.0 & -0.5 & -0.1 \\
\hline Caribbean & 0.0 & 0.1 & 0.4 & 0.3 & 0.5 & 0.3 & 0.0 & 0.0 & -0.2 & 0.0 & 0.2 & 0.0 \\
\hline Total LAC & 4.2 & 4.7 & 5.4 & 6.7 & 10.7 & 6.5 & 3.0 & 1.2 & 0.7 & -0.1 & -1.2 & 0.7 \\
\hline China & 9.1 & 3.3 & 16.4 & 2.7 & 1.2 & 5.3 & 8.0 & 2.0 & 5.7 & 1.2 & -0.5 & 2.5 \\
\hline India & 0.1 & 0.4 & 2.7 & 1.2 & 0.6 & 0.9 & 0.0 & 0.2 & 0.7 & 0.8 & -0.2 & 0.3 \\
\hline Other Asia & 18.6 & 6.6 & 8.6 & 8.3 & 3.6 & 8.3 & 8.9 & 2.3 & -0.6 & 1.1 & -2.3 & 1.6 \\
\hline Total Asia & 27.8 & 10.3 & 27.7 & 12.2 & 5.4 & 14.4 & 16.9 & 4.5 & 5.7 & 3.1 & -3.0 & 4.4 \\
\hline \multicolumn{13}{|l|}{ HIGH-QUALITY: } \\
\hline Brazil & 0.2 & 0.3 & 0.4 & 0.8 & 2.0 & 0.5 & 0.1 & -0.1 & 0.0 & -0.2 & 0.7 & 0.0 \\
\hline Mexico & 1.3 & 0.9 & 1.7 & 0.7 & 0.9 & 1.1 & 1.0 & 0.2 & 1.4 & 0.4 & 0.1 & 0.6 \\
\hline Rest of Mercosur & 0.0 & 0.2 & 0.3 & 0.5 & 1.9 & 0.3 & 0.0 & 0.0 & -0.1 & -0.2 & -0.2 & -0.1 \\
\hline Andeans & 0.0 & 0.2 & 0.4 & 1.1 & 3.3 & 0.6 & 0.0 & 0.1 & 0.1 & 0.2 & -0.2 & 0.0 \\
\hline Central A & 0.4 & 0.1 & 0.3 & 0.2 & 1.2 & 0.3 & 0.4 & 0.0 & 0.1 & 0.1 & 0.1 & 0.1 \\
\hline Caribbean & 0.0 & 0.1 & 0.2 & 0.3 & 0.4 & 0.1 & 0.0 & 0.0 & -0.1 & -0.1 & -0.2 & -0.1 \\
\hline Total LAC & 2.0 & 1.7 & 3.3 & 3.6 & 9.7 & 3.0 & 1.4 & 0.2 & 1.3 & 0.3 & 0.2 & 0.6 \\
\hline China & 3.9 & 1.3 & 5.0 & 2.1 & 2.0 & 2.7 & 3.4 & 0.9 & 2.0 & 1.0 & 0.1 & 1.6 \\
\hline India & 0.2 & 0.4 & 1.1 & 1.2 & 2.3 & 0.7 & 0.1 & 0.3 & 0.4 & 0.9 & 1.4 & 0.4 \\
\hline Other. Asia & 16.7 & 3.0 & 5.2 & 5.3 & 6.6 & 7.5 & 3.7 & 0.5 & -1.5 & 1.0 & -0.1 & 1.2 \\
\hline Total Asia & 20.8 & 4.8 & 11.2 & 8.6 & 10.9 & 11.0 & 7.2 & 1.7 & 0.9 & 2.9 & 1.4 & 3.2 \\
\hline
\end{tabular}

Note: Authors' calculations using BACI datasets. "HT" refers to high-tech manufactures, "MT" to medium-tech manufactures, "LT" to low-tech manufactures, "RB" to resource-based manufactures; and "PP" to primary products. 
APPENDIX C: AbSOLUTE CHANGES IN EXPORT SIMILARITIES AT THE VARIETY LEVEL, 1995- 2004

\begin{tabular}{|c|c|c|c|c|c|c|c|c|}
\hline & Brazil & Mexico & $\begin{array}{c}\text { Rest of } \\
\text { Mercosur }\end{array}$ & Andeans & $\begin{array}{c}\text { Central } \\
\text { America }\end{array}$ & Caribbean & China & India \\
\hline Brazil & . & & & & & & & \\
\hline Mexico & 1 & & & & & & & \\
\hline Rest of Mercosur & 1 & 1 & 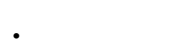 & & & & & \\
\hline Andeans & $\mathbf{0}$ & $\mathbf{0}$ & 2 & & & & & \\
\hline Central America & $\mathbf{0}$ & -3 & 0 & -1 & - & & & \\
\hline Caribbean & $\mathbf{0}$ & -1 & -1 & $\mathbf{0}$ & -3 & • & & \\
\hline China & 2 & 3 & -3 & $\mathbf{0}$ & -2 & -2 & & \\
\hline India & 5 & 9 & 5 & 3 & -3 & 3 & -2 & \\
\hline Other Asia & 3 & 4 & 0 & 0 & 0 & 0 & 2 & 2 \\
\hline
\end{tabular}

Note: Authors' calculations using BACI datasets. Figures in bold-italic indicate similarities above the mean. 


\section{APPENDIX D: DISTRIBUTION OF DISTANCE COEFFICIENTS OBTAINED} IN THE EXPLANATION OF EXPORT UNIT VALUES

\section{1) ${ }^{\circ}$ World exports}

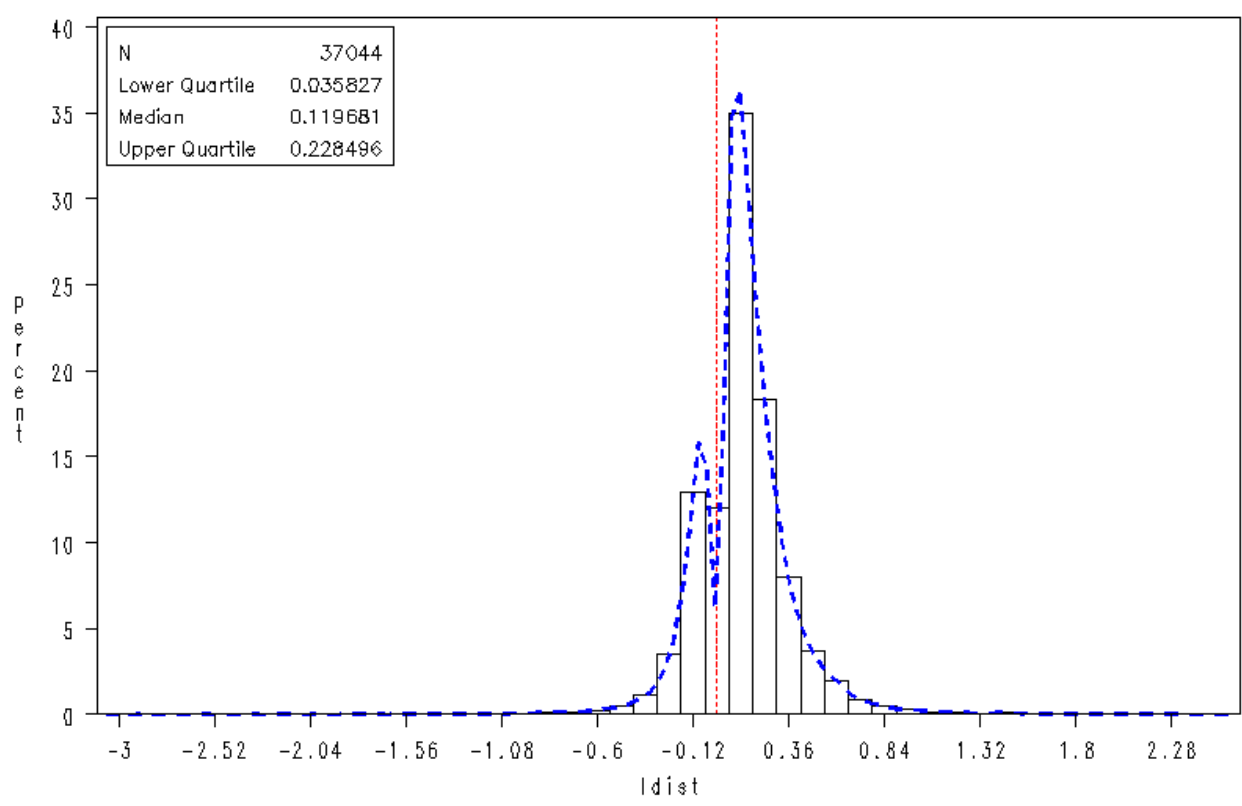

2) Asian exports

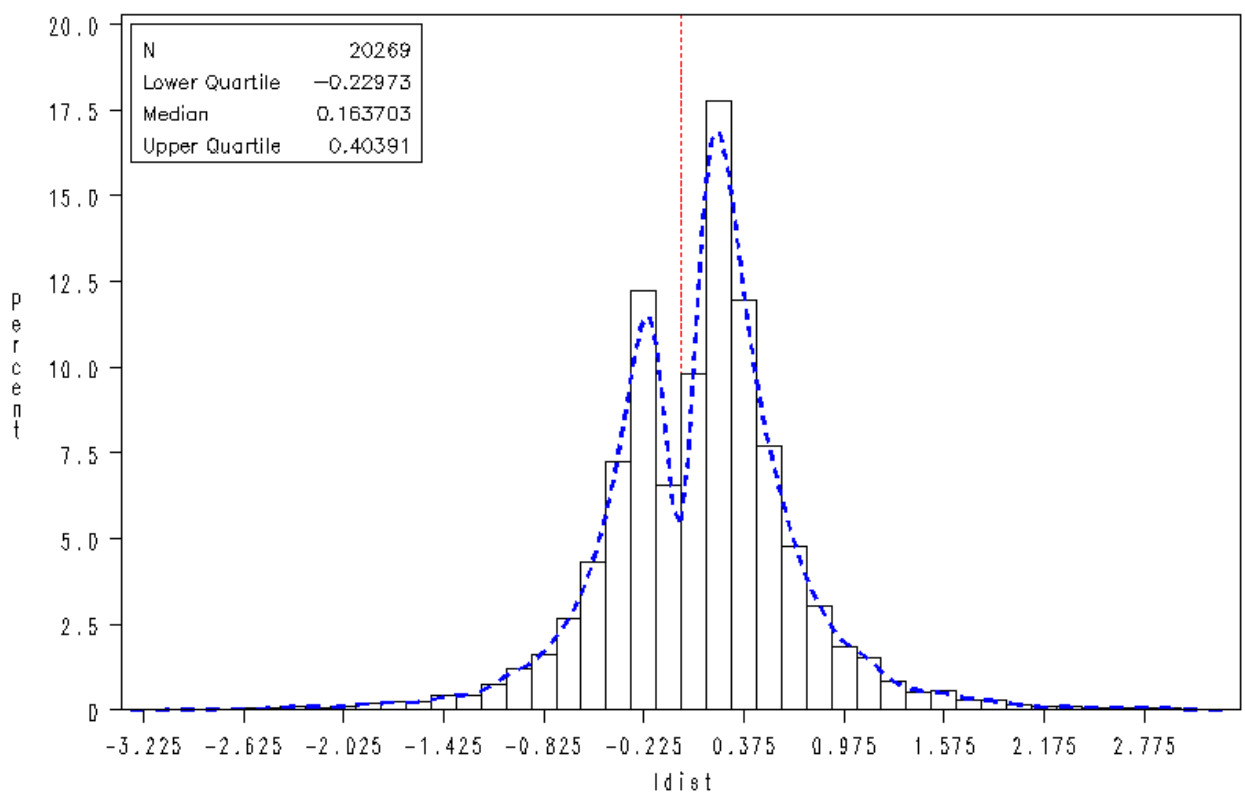




\section{3) LAC exports}

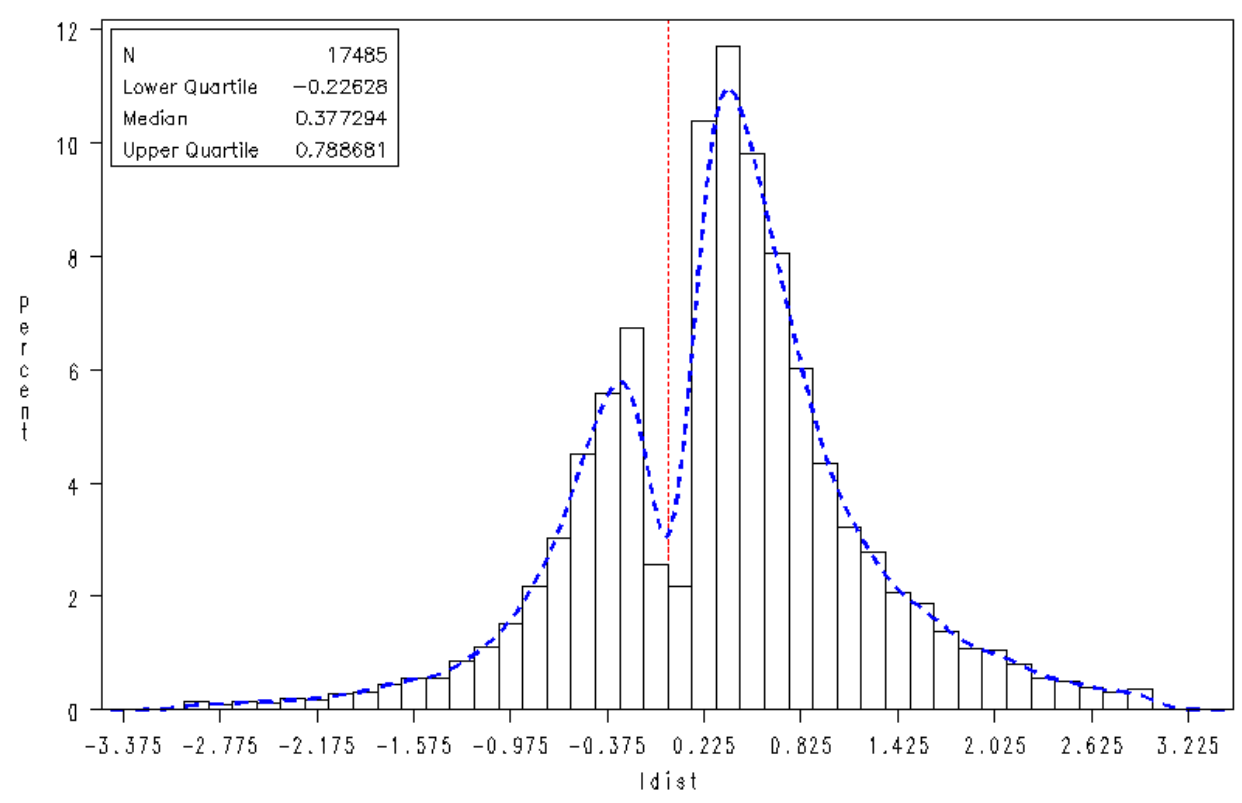




\section{LIST OF WORKING PAPERS RELEASED BY CEPII}

An Exhaustive list is available on the website: Ilwww.cepii.fr.

To receive an alert, please contact Sylvie Hurion (sylvie.hurion@cepii.fr).

No

Tittle

Authors

2009-08 The Dollar in the Turmoil

2009-07 Term of Trade Shocks in a Monetary Union: An Application to West-Africa

2009-06 Macroeconomic Consequences of Global Endogenous Migration: A General Equilibrium Analysis

2009-05 Équivalence entre taxation et permis d'émission échangeables

2009-04 The Trade-Growth Nexus in the Developing Countries: a Quantile Regression Approach

2009-03 Price Convergence in the European Union: within Firms or Composition of Firms?

2009-02 Productivité du travail : les divergences entre pays développés sont-elles durables?

2009-01 From Various Degrees of Trade to Various Degrees of Financial Integration: What Do Interest Rates Have to Say

2008-32 Do Terms of Trade Drive Real Exchange Rates? Comparing Oil and Commodity Currencies

2008-31 Vietnam's Accession to the WTO: Ex-Post Evaluation in a Dynamic Perspective

2008-30 Structural Gravity Equations with Intensive and Extensive Margins

2008-29 Trade Prices and the Euro

2008-28 Commerce international et transports : tendances du passé et prospective 2020

2008-27 The Erosion of Colonial Trade Linkages after Independence
A Bénassy-Quéré, S. Béreau \& V. Migon

L. Batté, A. Bénassy-Quéré, B. Carton \& G. Dufrénot

V. Borgy, X. Chojnicki, G. Le Garrec \& C. Schwellnus P. Villa

G. Dufrénot, V. Mignon \& C. Tsangarides

I. Méjean \& C. Schwellnus

C. Bosquet \& M. Fouquin

A. Bachellerie, J. Héricourt \& V. Mignon

V. Coudert, C. Couharde \& V. Mignon

H. Boumellassa \& H. Valin

M. Crozet \& P. Koenig

J. Martin \& I. Méjean

C. Gouel, N. Kousnetzoff \& H. Salman

T. Mayer, K. Head \& J. Ries 
No

2008-26 Plus grandes, plus fortes, plus loin... Performances relatives des firmes exportatrices françaises

2008-25 A General Equilibrium Evaluation of the Sustainability of the New Pension Reforms in Italy

2008-24 The Location of Japanese MNC Affiliates:

Agglomeration, Spillovers and Firm Heterogeneity

2008-23 Non Linear Adjustment of the Real Exchange Rate Towards its Equilibrium Values

2008-22 Demographic Uncertainty in Europe - Implications on Macro Economic Trends and Pension Reforms - An Investigation with the INGENUE2 Model

2008-21 The Euro Effects on the Firm and Product-Level Trade Margins: Evidence from France

2008-20 The Impact of Economic Geography on Wages: Disentangling the Channels of Influence

2008-19 Do Corporate Taxes Reduce Productivity and Investment at the Firm Level? Cross-Country Evidence from the Amadeus Dataset

2008-18 Choosing Sensitive Agricultural Products in Trade Negotiations

2008-17 Government Consumption Volatility and Country Size

2008-16 Inherited or Earned? Performance of Foreign Banks in Central and Eastern Europe

2008-15 The Effect of Foreign Bank Entry on the Cost of Credit in Transition Economies. Which Borrowers Benefit most?

2008-14 Contagion in the Credit Default Swap Market: the Case of the GM and Ford Crisis in 2005.

2008-13 Exporting to Insecure Markets: A Firm-Level Analysis

2008-12 Social Competition and Firms' Location Choices

2008-11 Border Effects of Brazilian States

2008-10 International Trade Price Indices

\section{Authors}

M. Crozet, I. Méjean \& S. Zignago

R. Magnani

T. Inui, T. Matsuura $\&$ S. Poncet

S. Béreau,

A. Lopez Villavicencio \& V. Mignon

M. Aglietta \& V. Borgy

A. Berthou \& L. Fontagné

L. Hering \& S. Poncet

J. Arnold

\& C. Schwellnus

S. Jean, D. Laborde \& W. Martin

D. Furceri

\& M. Poplawski Ribeiro

O. Havrylchyk \& E. Jurzyk

H. Degryse,

O. Havrylchyk, E. Jurzyk \& S. Kozak

V. Coudert \& M. Gex

M. Crozet, P. Koenig \& V. Rebeyrol

V. Delbecque, I. Méjean \& L. Patureau

M. Daumal \& S. Zignago

G. Gaulier, J. Martin, I. Méjean \& S. Zignago 
No

2008-09

Base de données CHELEM - Commerce international du CEPII

2008-08 The Brain Drain between Knowledge Based Economies: the European Human Capital Outflows to the US

2008-07 Currency Misalignments and Exchange Rate Regimes in Emerging and Developing Countries

2008-06 The Euro and the Intensive and Extensive Margins of Trade: Evidence from French Firm Level Data

2008-05 On the Influence of Oil Prices on Economic Activity and other Macroeconomic and Financial Variables

2008-04 An Impact Study of the EU-ACP Economic Partnership Agreements (EPAs) in the Six ACP Regions

2008-03 The Brave New World of Cross-Regionalism

2008-02 Equilibrium Exchange Rates: a Guidebook for the EuroDollar Rate

2008-01 How Robust are Estimated Equilibrium Exchange Rates? A Panel BEER Approach

\section{Authors}

A. de Saint Vaulry

A. Tritah

V. Coudert\& C. Couharde

A. Berthou \& L. Fontagné

F. Lescaroux\& V. Mignon

L. Fontagné, D. Laborde \& C. Mitaritonna

A. Tovias

A. Bénassy-Quéré, S. Béreau \& V. Mignon

A. Bénassy-Quéré, S. Béreau \& V. Mignon 
Organisme public d'étude et de recherche en économie internationale, le CEPII est placé auprès du Centre d'Analyse Stratégique. Son programme de travail est fixé par un conseil composé de responsables de l'administration et de personnalités issues des entreprises, des organisations syndicales et de l'Université.

Les documents de travail du CEPII mettent à disposition du public professionnel des travaux effectués au CEPII, dans leur phase d'élaboration et de discussion avant publication définitive. Les documents de travail sont publiés sous la responsabilité de la direction du CEPII et n'engagent ni le conseil du Centre, ni le Centre d'Analyse Stratégique. Les opinions qui y sont exprimées sont celles des auteurs.

Les documents de travail du CEPII sont disponibles sur le site : http//www.cepii.fr.

CEPII

9, RUe Georges Pitard, 75740 Paris Cedex 15

SYLVIE HURION - PUbliCATIONS

TÉL : 0153685514 - FAX : 0153685504

sylvie.hurion@cepii.fr

ISSN : 1293-2574 